\title{
ENTRE OS SIGNIFICADOS INTERNOS E EXTERNOS: A TOTALIDADE OCULTA DA VIDA E A EXPERIÊNCIA LITERÁRIA
}

\author{
Amanda Moury Fernandes Bioni \\ Mestranda em Teoria da Literatura pela Universidade Federal de Pernambuco (UFPE) \\ manda.m.f.bioni@gmail.com
}

\section{RESUMO}

O presente artigo objetiva realizar uma breve análise sobre a convencionalidade, relativa à empreitada literária, em funcionar como um objeto de conhecimento da condição humana, especialmente, no contexto contemporâneo. Dessa maneira, a relação entre o interno e o externo é discutida, tendo em vista os gêneros literários modernos, como o romance e o poema em prosa, observando suas capacidades de representação das circunstâncias humanas, à proporção que sinaliza, assim, uma relação de causa e de consequência entre a expressão particular (localizada) e os significados universais.

Palavras-chave: Estudos Literários; texto e contexto; totalidade oculta da vida.

\begin{abstract}
This article aims at making a brief analysis of the literary endeavor's conventionality of functioning as an object of knowledge of the human condition, especially in the contemporary context. In this way, the relationship between the internal and the external meanings is put to discussion, considering modern literary genres as the novel and the prose poem, observing their capacities of representation of the human circumstance, while signaling a relation of cause and consequence between particular (localized) expression and universal meanings.
\end{abstract}

Keywords: Literary Studies; text and context; hidden totality of life.

\section{A Literatura Nacional como uma manifestação artística situada: discussão inicial sobre as relações entre Literatura, História e Sociedade}

O relacionamento entre o discurso literário e o discurso histórico ainda é um tema

recorrente nas mesas de debate entre os teóricos. Por se constituírem como narrativas

que avaliam o homem em dado contexto social, muitos estudiosos, críticos e filósofos não 
resistiram à necessidade de observá-las, realizando, como consequência, uma espécie de comparação a fim de encontrar e distinguir suas peculiaridades. Já é possível perceber na Poética de Aristóteles uma primária distinção entre as funcionalidades poéticas e históricas. Para o estagirita, a poesia é mais nobre e mais filosófica do que a história, e, portanto, mais universal. Já a história se responsabilizaria pelo particular. A diferença entre as duas não se estabelece através da forma, mas sim, pelo conteúdo: a história se refere aos eventos ocorridos de fato, enquanto que a poesia se refere aos eventos que poderiam ter ocorrido. ${ }^{1}$

Apesar de pertinentes, as afirmações aristotélicas sobre os conteúdos e funcionalidades da história e do poema não foram o bastante para os investigadores dos respectivos ramos, especialmente os ditos modernos. Estabelecer o objeto de estudo da história constituiu uma inquietação constante aos apreciadores de artefatos e documentos antigos, em paralelo, os homens das letras tentavam compreender os estímulos e as consequências sociais do fazer literário. E, os meios de tais investidas teóricas, geralmente, se baseavam na contraposição entre história e literatura. ${ }^{2}$ Em termos de resultados, se poderia dizer que a história colhe os fatos, enquanto a literatura oferta a ficção. Contudo, esses limites não são suficientes e até questionáveis, pois, nos princípios do século XVII inglês, a palavra novel se referia, ao mesmo tempo, a acontecimentos reais e fictícios (EAGLETON, 1994).

Então, se não basta especificar as narrativas literárias e históricas por meio da diferença, seria satisfatório através de semelhanças ou aproximações? Talvez, seja o que Hayden White (1974) tentou fazer ao defender que as narrativas históricas são tão inventadas quanto as tramas literárias, constituindo-se, assim, como ficções verbais. ${ }^{3} \mathrm{O}$ argumento do historiador americano se pauta no modo pelo qual o historiador 
profissional estrutura e harmoniza a narrativa, conferindo-Ihe um sentido particular. É óbvio que essa afirmação recebeu muitas considerações. Uma das mais pertinentes foi a de Luiz Costa Lima (2006), que embora reconheça o esforço teórico de Hayden White, discorda de que a história seja equivalente à literatura, pelo simples caso de a escrita histórica buscar desvendar o que é e foi, e se constituir, dessa maneira, como uma aporia; já a ficção se isenta do compromisso com a veracidade, sendo, portanto, porosa. ${ }^{4}$

Apesar das particularidades, história e literatura convergem por meio da utilização da linguagem como forma de expressão e por meio da avaliação do homem no decorrer dos tempos. ${ }^{5}$ Contudo, essa convergência é meramente tangencial, especialmente se temos em conta a sutileza entre o fato e o evento. Os fatos se relacionam muito mais ao que ocorreu, ao que não se pode, ou não se deve duvidar. É o território da comprovação documentada. Já o evento, derivado de eventum, supino de evenire, se relaciona com o vir, sendo assim, compreende o acaso e o acidente, no sentido de romper com a uniformidade estabelecida. Se associarmos os fatos à história e o evento à literatura, teríamos, de certa forma, um resgate do pensamento aristotélico ${ }^{6}$ : apesar de se formarem em narrativas, uma depende da credibilidade e anseia pela veracidade, a outra não estabelece fronteiras, mas abre caminhos, não é menos verdadeira, porém, às vezes, estreia suspeitas. É por esses e outros motivos que a literatura não pode se reduzir à categoria de epifenômeno da história.

Entretanto, ao considerarmos os projetos relativos às literaturas nacionais, nos é apresentada a abrupta sobreposição do contexto histórico à individualidade criadora. Sobre esse aspecto, é importante observar as influências da práxis na atividade literária. Entendendo a literatura como uma expressão essencialmente linguística, não podemos ignorar a influência da práxis na interpretação dos referentes sociais. Conforme Izidoro 
Blikstein (2003, p. 61-65 grifos do autor) “[...] a práxis opera em nosso sistema perceptual, ensinando-nos a 'ver' o mundo com os 'óculos sociais' [...] com os estereótipos gerados pelos corredores isotópicos é que 'vemos' a realidade e fabricamos o referente". Dessa forma, a composição ficcional está condicionada à apreciação de um constructo social em vigência e às consequentes especulações e reformulações fundamentais à implementação de realidades fabricadas pela palavra artística.

Reconhecendo a importância dos aspectos sociais na composição literária, Antonio Candido (2006) determina um esquema tríplice de mútua interdependência: autor, obra e leitor. Com relação aos estímulos do fazer literário, Antonio Candido destaca a satisfação das necessidades espirituais e materiais e sua convivência com determinada situação social: o escritor, socialmente condicionado, quer atingir determinado fim, o leitor deseja conhecer determinado aspecto da realidade; logo, o sentido da obra também se efetiva socialmente: a obra literária se assume como um sistema simbólico de comunicação. ${ }^{7}$ Esse sistema se estrutura a partir de denominadores comuns que atestam as notas dominantes de uma fase e participam da continuidade literária. Sendo assim, com a finalidade de garantir a indispensável aceitação social, o texto deveria se apossar do contexto histórico e ideológico, não como ingrediente, mas como integrante da mensagem: o externo se torna interno quando o contexto não está apenas referido, porém é parte da obra (CANDIDO, 2006). E, assim, pode ser reconhecido e constantemente retomado, contribuindo à manutenção do sistema.

É notória a contribuição dos esforços teóricos de Antonio Candido em esclarecer o convívio entre a literatura e os seus constituintes sociais e ideológicos. Todavia, em um país tão diversificado, em termos culturais e econômicos, como o Brasil, um projeto uniforme de literatura nacional parece utópico. ${ }^{8}$ É pertinente reconhecer que o vínculo 
entre a produção narrativa e os fatores externos é amistoso, porém, não necessariamente, determinante e redutor. É inquestionável que a narrativa literária age no tempo dos homens e, consequentemente, comunica ao processo histórico e social, através de uma forma que tenta compreendê-lo de um jeito particular. Então, nos parece que a expressão literária não deve se aprisionar a um contexto histórico controlador, e, por consequência, esterilizar toda sua potencialidade significativa. Se aceitamos isso, também concordamos que a literatura transcende os fatos históricos, como se os captasse de uma maneira apropriadora: o alheio se torna próprio, e então, a forma literária pode proceder espontaneamente, escapando, como um peixe ensaboado, a

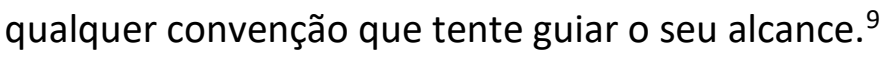

Os tempos modernos adaptaram os velhos paradigmas às suas exigências. É válido lembrar que com as invenções tecnológicas, o mundo parece estar menor, embora as pessoas se comportem, cada vez mais, de modo individualizado. Não é surpreendente que as relações entre o escritor, a obra e o público tenham acompanhado o progresso e se inserido no mercado. Para além da estética do consumo imediato, o presente ensaio busca refletir sobre os meios que possibilitam o encerramento dialético entre o eu e o outro, o sujeito e o objeto através de uma individualidade criadora. Além disso, também é válido pensar sobre a questão das literaturas nacionais ou da literatura de gênero em um mundo cada vez mais multifacetado e disperso.

\section{Entre os textos e os contextos: formas de reapresentar a realidade}

A realidade, isto é, esse tempo e esse espaço social que envolvem e definem a existência humana, por muitas épocas, foi e ainda continua a ser um motivo à curiosidade do homem. E porque a realidade, tal como a entendemos, parece não bastar ou se 
reduzir às especulações científicas, o homem, desde os primórdios, é impelido a realizar a mimese produtiva ${ }^{10}$, como se esta fosse uma característica inerente à sua condição de homem:

[...]de fato, a ação de mimetizar se constitui nos homens desde a infância, e eles se distinguem das outras criaturas porque são os mais miméticos e porque recorrem à mimese para efetuar suas primeiras formas de aprendizagem, e todos se comprazem com as mimeses realizadas. (ARISTÓTELES, 2015, V. Poética 48b4)

A mimese, segundo Aristóteles, se pauta nas ações da vida, e sendo assim, é um conceito substancial ao empreendimento de perscrutar a realidade com o auxílio das formas artísticas. O filósofo grego nos ofereceu um tratado sobre a arte poética, em termos de estrutura, características e funcionalidades. Com respeito às tragédias, seria dever do bom poeta, ao se utilizar do conjunto de técnicas estabelecido, elaborar um enredo (mýthos) capaz de promover a catarse (kátharsis), ou seja, o ato de purificação emocional à plateia. Esse efeito precisava ser obtido, a fim de garantir a funcionalidade da tarefa empreendida pelo poeta, que ao realizar uma releitura dos mitos da civilização grega, construía uma unidade textual (início, meio e fim), e no momento adequado, deveria mostrar a cena da falha trágica (hamartía), em que o herói trágico passa da prosperidade à adversidade, culminando no seu fim desastroso. Assim, se conformavam as três partes do enredo: reviravolta, reconhecimento e comoção emocional (páthos).

Quanto à epopeia, o teórico grego, apesar de reconhecer a maestria de Homero, considerou o gênero inferior à tragédia. Além disso, observou que a epopeia e a tragédia se assemelhavam quanto à mimese das ações de homens elevados, porém, divergiam quanto à forma e à extensão. Ademais da sistematização dos gêneros miméticos, tão 
fundamentais a uma percepção diferenciada da realidade, a obra aristotélica foi propulsora de investigações posteriores acerca dos gêneros literários.

Com o objetivo de elucidar a estética romântica, em termos de forma e de conteúdo, Georg Lukács $(1965)^{11}$ nos oferece um ensaio histórico-filosófico que remete às formas épica e trágica. Com o objetivo de tornar a exposição mais clara, a abordagem da obra do teórico húngaro se estrutura em duas partes. A primeira, trata dos pareceres sobre os gêneros clássicos sob uma ótica comparativa e a segunda se refere às características do romance moderno.

A epopeia é um gênero literário que tematiza as aventuras de um personagem heroico, o qual sintetiza os valores de uma nação. ${ }^{12}$ Através de sucessivas aventuras, carregadas de perigo e de mistério, Ulisses lida com os deuses e ao mesmo tempo, utiliza a razão para se livrar dos impasses, como no caso do cavalo de Tróia; e também, a astúcia Ihe serve para satisfazer a sua curiosidade, como no episódio das sereias. É uma narrativa que assume os mitos, as divindades e a razão, porque a comunidade também compartilhava desses dilemas e dessas ocasiões, de modo que o herói nunca é apenas um indivíduo. O trajeto percorrido pelo herói apresenta uma lógica circular, semelhante à perspectiva existencial no mundo grego: os traumas do progresso ainda não haviam sido descobertos. Então, se conformava uma realidade fechada, determinada por uma expectativa comunitária, em que o herói é a medida do mundo, e ao ultrapassar as adversidades, através de suas atitudes existenciais, conquista a totalidade essencial, que por sua vez, corresponde à totalização da comunidade..$^{13}$

Por outro lado, a tragédia se pauta no drama de uma essencialidade atribuída que é posta à prova a partir da existência. O herói trágico tem um caráter elevado e aprecia os valores morais, contudo, sua ação é capaz de romper a harmoniosa ordem do universo: 
institui-se a falha trágica (harmatía), pois o destino do herói é tributário da vontade dos deuses. É quando Édipo se sente capaz de alterar o próprio destino e abandona a família adotiva para ir ao encontro da família biológica, assassinar o pai e se casar com a mãe, cumprindo assim, a profecia, o desígnio divino. Ao passar da prosperidade à adversidade, o herói trágico experimenta sozinho o seu drama, à proporção que serve como um exemplo à plateia que experimenta o efeito catártico. ${ }^{14}$

A solidão e o abandono dos deuses ${ }^{15}$ são temas atualizados pela forma romântica, dadas as suas peculiaridades e diferenças sociais e históricas. Por ser uma estética da modernidade e do consequente progresso, uma perspectiva circular, que vise a propor, através das artes, um ideal de ética e de valores morais coletivos, não é adequada. A justificativa é breve: porque o mundo atual não é mais homogêneo e previsível, ao ponto de alguém acreditar que tudo está no mesmo lugar no dia seguinte ou na volta de uma longa jornada; há o movimento constante, de uma maneira que a reversibilidade é uma ilusão necessária à manutenção dos dias e das noites: nada é como antes, embora pareça que é, devido à utilidade profissional do tempo. É nessa realidade de incertezas e de contradições que romântico moderno introduz a produtividade do espírito. ${ }^{16} \mathrm{E}$ não é à toa que Georg Lukács afirma repetidas vezes que o romance é a forma da virilidade madura, capaz de descobrir e construir a totalidade oculta da vida. ${ }^{17}$ Não é surpresa, pois, que a relação entre texto, obra e autor tenha experimentado modificações e que os projetos de literatura nacional admitam um semblante obtuso:

Assim, esse primeiro grande romance da literatura mundial situa-se no início da época em que o deus do cristianismo começa a deixar o mundo; em que o homem torna-se solitário e é capaz de encontrar o sentido e a substância apenas em sua alma, nunca aclimatada em pátria alguma; em que o mundo, liberto de suas amarras paradoxais no além presente, é abandonado a sua falta 
de sentido imanente; em que o poder do que subsiste - reforçado por laços utópicos, agora degradados à mera existência. (LUKÁCS, 2015, p. 106) ${ }^{18}$

E a partir daí, reconhecemos que o personagem principal da narrativa romântica não se adequa ao mundo, pois o mundo não é mais a sua medida. Esse conflito entre a subjetividade e o mundo só pode conformar-se a partir da ironia: “[...] para o romance, a ironia é essa liberdade do escritor perante deus, a condição transcendental da objetividade da configuração" (LUKÁCS, 2015, p.95). E mais: a ironia se constitui como a autossuperação da subjetividade, porque a forma romanesca é abstrata e perigosa e se insere em um projeto de um homem só; de modo que ao pensarmos no resgate das referências sociais de uma época, a ironia se mostra como um abismo entre a palavra e a coisa. Há um ruído de comunicação que precisa ser decifrado pelo leitor atento e tão afetado pelas frustrações modernas quanto o escritor. Há uma espécie de compartilhamento que não é cativo de questões meramente ideológicas.

Nas palavras de Antoine Compagnon (2014, p.36): “A subjetividade moderna desenvolveu-se com a ajuda da experiência literária, e o leitor é o modelo de homem livre. Atravessando o outro, ele atinge o universal". Essa façanha de harmonizar esse par dialético é possível através da forma e de uma revelação poética. ${ }^{19}$ É óbvio que a forma encaixada em determinada construção social e histórica suscita meios sitiados de desenvolvimento temático e estético. Contudo, no contexto da era da virilidade madura, em termos estéticos, a totalidade conceitual e formal do mundo não é mais possível, e assim, se institui a fragmentação, a reunião de todas as formas, a quebra de expectativas, e os modelos de gêneros literários consolidados se convertem em matéria-prima para o experimentalismo necessário a tornar satisfatório o entrelaçamento reverso entre texto e 
contexto: esse é o movimento ${ }^{20}$ em busca da compreensão sobre a totalidade oculta da vida.

Finalmente, é preciso perceber que "[...] A arte, a realidade visionária do mundo que nos é adequado, tornou-se assim independente: ela não é mais uma cópia, pois todos os modelos desapareceram; é uma totalidade criada, pois a unidade natural das esferas metafísicas foi rompida para sempre" (LUKÁCS, p. 34, 2015). O advérbio "sempre", apesar de possuir uma conotação positiva se associado ao "nunca", proporciona uma espécie de condenação, de seguir apenas um sentido único interminável. As categorias do tempo eterno também constituem totalidades criadas. O mito é uma totalidade criada, uma forma simples, derivada de perguntas e de respostas. Então, é oportuno pensar por quais artifícios a forma da virilidade madura explorou as dimensões das formas simples, com o objetivo de tatear a totalidade oculta da existência em uma era de mentes desencontradas.

\section{Entre o eu e o outro: formas de responder à totalidade do espírito}

A literatura entendida como uma composição capaz de capaz de harmonizar os espíritos, através da palavra organizada, é também proposta como um direito essencial à humanidade por Candido (1995). Dentre outros motivos, a obra literária é benéfica ao espírito porque estabelece a superação do caos, pois “[...] o conteúdo só atua por causa da forma, e a forma traz em si, virtualmente, uma capacidade de humanizar devido à coerência mental que pressupõe e que sugere" (p.178). E, assim, a individualidade criadora consolida uma proposta de sentido capaz de nos libertar da barbárie. Então, podemos supor que a literatura possui uma lógica particular atenta à preservação do espírito, apesar de não ser objetivamente definível ${ }^{21}$. De modo semelhante, André Jolles 
(1976) afirma que os mitos se constituem como narrativas primordiais e que também possuem uma lógica particular imbuída no momento em que o homem interroga o universo: "quando o universo se cria assim para o homem por pergunta e resposta, tem lugar a forma a que chamamos mito" ( $p .88$, grifos do autor). Dessa maneira, percebemos que tanto o mito quanto a literatura se compõem a partir de linguagem, e além disso, respondem às perguntas de modo criativo. Porém, a partir de que critério cada um inaugura a sua lógica particular?

Tanto o mito como a literatura possuem, à sua maneira, um caráter predicativo. Sempre atribuem algum sentido, alguma perspectiva à convenção dos fatos. Entretanto, enquanto os relatos míticos se originam para além dos acontecimentos históricos, a literatura está sujeita ao momento histórico e social da produção. Como bem notou Eudoro de Sousa (1981): “[...] A história com o seu antigo-distante, não passa do lado de cá para o lado de lá do horizonte, mas o mito passa de lá para cá [...] O distante e o antigo perdem-se na lonjura e no outrora, que são indimensionais dimensões do mítico" (p.1819). Sendo assim, o mito se constitui como uma verdade absoluta, fechada em si mesma: “[...] Um único fenômeno se faz conhecer completamente no mito e, assumindo sua independência, separa-se de todos os outros fenômenos [...] O mito é a Forma Simples" (JOLLES, 1976, p.90, grifos do autor). Portanto, a distinção entre mito e literatura pode se resumir a partir da funcionalidade referente ao conteúdo e à forma, que condiciona as necessidades do saber e do dizer, do questionar e do responder: o mito atrai para si a verdade universal, já a literatura, como manifestação artística e cultural, só pode entregar ao mundo uma impressão de verdade tangenciada: “[...] o ficcional é um instrumento limitado, pois não oferece respostas cabais e plenas. É nisso mesmo que está o seu limite e sua maior qualidade". (LIMA, 1988, p.309). 
Porém, esse reconhecimento não quer afirmar que a literatura seja apenas uma forma de dizer bem-comportada: a emancipação conquistada pela estética da virilidade madura concentrou traços de subversão. O contexto foi chamado à composição da obra, mas não como hóspede privilegiado, antes teve que se submeter às pretensões do texto, antes precisou passar pelo olhar da individualidade criadora, e então, se tornar matéria estética, se tornar obra. ${ }^{22}$ Essa conversão é consequência da dissonância do mundo moderno que instituiu a dispersão entre o escritor e o leitor: a "comunicação" se pauta na distância, porque o mundo perdeu as medidas e os modelos. Emissor e receptor não se encontram mais e a obra é o elo entre perspectivas distantes. Então, como resgatar o efeito catártico? Como alcançar o outro desconhecido? Como estabelecer a proposta de sentido? Como tocar o espírito? Através dos modelos clássicos adulterados e de uma linguagem que se mantém eficiente, porque significa e sugere à exaustão (Cf. POUND, 2006). Não é de se espantar que essas formas não podem ser simples e que o leitor não pode esperar pelo sentido convencional. A abertura do texto ao leitor institui uma cooperação, por meio da qual a distância é driblada; o leitor é coautor (Cf. CARRETER, 1980). E, talvez, cúmplice a experimentar o desencantamento do mundo:

Nesse processo, a própria alienação torna-se um meio estético para o romance. Pois quanto mais se alienam uns dos outros os homens, os indivíduos e as coletividades, tanto mais enigmáticos eles se tornam uns para os outros. 0 impulso característico do romance, a tentativa de decifrar o enigma da vida exterior, converte-se no esforço de captar a essência, que por sua vez aparece como algo assustador e duplamente estranho no contexto do estranhamento cotidiano imposto pelas convenções sociais. O momento antirrealista do romance moderno, sua dimensão metafísica, amadurece em si mesmo pelo seu objeto real, uma sociedade em que os homens estão apartados uns dos outros e de si mesmos. Na transcendência estética reflete-se o desencantamento do mundo. (ADORNO, p. 58, 2003) 
Esse desencantamento do mundo poderia se organizar em linguagem eficiente através do verso ou da prosa, e até da síntese criativa entre os dois. Já afirmava Lukács (2015, p.72 grifos do autor) que “[...] a arte - em relação à vida - é sempre um "apesar de tudo"; a criação de formas é a mais profunda confirmação que se pode pensar da existência da dissonância." E, não seria um exagero admitir que o simbolismo do século XIX se constituiu como um marco na reflexão sobre a linguagem, o que repercutiu na maleabilidade formal. Em Embriaga-te $(1869)^{23}$, as palavras escritas e organizadas em forma subversiva por Charles Baudelaire ofertam um conselho imperativo: para aqueles que não querem ser os escravos martirizados do tempo, a solução é a embriaguez de vinho, de poesia ou de virtude. É o desacordo entre o indivíduo e as circunstâncias brutais do mundo moderno posto em linguagem eficiente. $E$, apesar de essa mensagem se situar em um tempo e um espaço definidos, não conhece fronteiras: seus ecos ainda perturbam, à proporção que uma comunhão de leitores desencantada, busca resgatar e atribuir significados à tragédia existencial, e assim, acessar, por uma das rachaduras, a totalidade oculta da vida.

Quanto à prosa, as reflexões metafísicas, o psicologismo e as descobertas científicas acrescentaram rumos e nuances à trajetória do herói, que não é mais tão nítido e louvável quanto Ulisses, nem tão resignado ao seu destino catastrófico quanto Édipo. Oscar Wilde arquitetou com maestria um personagem que tentou escapar das amarras do tempo: Dorian Gray ${ }^{24}$, um jovem de beleza impressionante e com boas intenções, até se tornar o objeto de comprovação teórica e científica de Lord Henry Wotton, o qual, através de palavras, persuade o jovem rapaz a vender sua alma em troca da juventude eterna: isso acontece quando Dorian contempla sua imagem ao retrato e toma consciência do seu poder, da sua beleza. E, semelhante a Narciso, estava 
condenado a não se conhecer, porque isso, o levaria à destruição. Entretanto, no romance de Oscar Wilde, Dorian Gray não conhece profecias sobre o seu destino, mas sim especulações filosóficas e projeções fatalistas, acentuadas por uma boa retórica. Os motivos são plausíveis à modernidade, embora haja levantado polêmicas na sociedade inglesa do século $\mathrm{XIX}$, porque o susto foi forte demais ao reconhecer na imagem degradada e monstruosa de Dorian ao retrato, o espírito dos tempos modernos, em que a tentativa de escapismo à violência existencial se reduzia a vícios e a aventuras inadequadas ${ }^{25}$. Em síntese, Dorian Gray é um exemplo de que os heróis clássicos não se adequam ao mundo moderno, porque o anti-herói romântico é tragado pelo mundo e não há um deus ex machina.

Além disso, as consequências da eternidade são retomadas em outros contextos, através de outras formas, como é o caso do conto fantástico, intitulado La pata de palo de José de Espronceda. O relato sugere que é preciso ter cuidado com os desejos e que a satisfação plena jamais será gratuita: o universo tem seus preços pelos seus truques. E, que a eternidade é algo incompatível aos mortais, por isso mesmo, não se deve desejá-la. Na verdade, a satisfação desse desejo implica a reclusão em um tempo que nunca se acabará; e assim, o desfrute é escravidão: através do contexto em forma temos a afirmação pela diferença e o encerramento de pares dialéticos.

Sobre esse aspecto, é importante perceber que os pares dialéticos também se configuram e se harmonizam poeticamente, em versos, em imagem e em ritmo. Um retrato do indivíduo moderno é elaborado em palavra artística no poema homônimo de Cecília Meireles, publicado em 1937. Nesse poema, o eu-lírico não encontra sua face ao espelho, apesar de se surpreender com as mudanças tão simples, tão certas e tão fáceis que o tempo Ihe atribuiu. É como se estivéssemos diante da discórdia primordial (Cf. 
LACAN, 1966) entre o indivíduo e a imagem refletida, ocasionada pela projeção do outro, isto é, de uma imagem primordial, ou a essencialidade. Esse poema sugere, mais uma vez, que as descobertas plenas, o alcance à essencialidade são tarefas que competem ao mítico, ao divino, que são categorias que se situam além do limitado conhecimento humano: a totalidade da vida sempre será uma sombra à nossa situada percepção. É por isso que nós perdemos nossas faces diariamente, porque a cada dia somos um pouco diferentes do que éramos; a cada dia há uma reconstrução, uma reinvenção da vida ${ }^{26}$. A unidade dessa consciência caótica só pode ser configurada esteticamente, através da forma e da revelação poética: há a conciliação entre o sujeito e ele mesmo, entre o sujeito e o mundo, entre o sujeito e o outro, a partir da totalidade criada:

\begin{abstract}
A imagem não explica: convida-nos a recriá-la e, literalmente, a revivê-la. 0 dizer do poeta se encarna na comunhão poética. A imagem transmuta o homem e converte-o por sua vez em imagem, isto é, em espaço onde os contrários se fundem. E o próprio homem, desgarrado desde o nascer, reconcilia-se consigo quando se faz imagem, quando se faz outro. [...] A poesia coloca o homem fora de si e, simultaneamente, o faz regressar ao seu ser original: volta-o para si. O homem é a sua imagem: ele mesmo e aquele outro. (PAZ, 1976, p. 50, grifos do autor)
\end{abstract}

É nesse espaço de leitura intertextual pautada na criação de imagens que "[...] o leitor reconhece a sua condição histórica ao revolver, para poder ouvir o que diz o poeta, a linguagem refletida de sua própria experiência." (BARBOSA, 1986, p.23) E como o sentido do poema moderno não é dado facilmente, o leitor se torna cúmplice na decifração dessa linguagem que tende ao universalismo: “[...] entendida assim a universalidade, compreende-se que a leitura do poema moderno tenha que operar num processo de intensa reversibilidade dos valores espaciais e temporais" (BARBOSA,1986, p. 37). Essa reversibilidade dos valores espaciais e temporais pode nos remeter ao mítico, 
todavia essa opção seria um desvio, pois o poema, a linguagem literária não aspira à verdade, tendo por compromisso dizer o que poderia ser e não absolutamente o que é:

\footnotetext{
Épica, dramática ou lírica, condensada em uma frase ou desenvolvida em mil páginas, toda imagem aproxima ou conjuga realidades opostas, indiferentes ou distanciadas entre si. Isto é. Submete à unidade a pluralidade do real [...] Portanto, a realidade poética da imagem não pode aspirar à verdade. O poema não diz o que é e sim o que poderia ser. (PAZ, 1976, p. 38)
}

Sendo assim, a marca da virilidade madura também se apresenta em poesia, porque inaugura uma alternativa ao real e porque pretende incomodar e não se acomodar. É esse impulso norteador da palavra artística que encontrou a liberdade, a maturidade e "[...] recusa os piedosos, mas perigosos e redutores, esquemas de classificação entre poemas mais ou menos importantes conforme privilégios nacionalistas." (BARBOSA,1986, p.37). Portanto, a forma e a revelação poética se afirmam como duas fortes candidatas ao entusiasmo moderno de reversibilidade artística: ao contrário de propor mundos convencionalizados e harmônicos, o discurso ficcional apresenta o nosso mundo como um mundo impossível (Cf. SEGRE, 1985). E é nesse aspecto que a individualidade criadora direciona a sensibilidade comum ao encontro de formas que organizem possibilidades de vislumbrar a totalidade oculta da existência e a efemeridade ignorada da vida.

\section{Referências}

ADORNO, Theodor W. Posição do narrador no romance contemporâneo. In: Notas de Literatura I. Tradução e apresentação de Jorge M. B. de Almeida. São Paulo: Duas Cidades; Editora 34, 2003, pp. 55-63.

ARISTÓTELES. Poética. Edição bilíngue. Tradução, notas e introdução de Paulo Pinheiro. São Paulo: Editora 34, 2015. 
BARBOSA, João Alexandre. As ilusões da modernidade. São Paulo: Perspectiva, 1986.

BAUDELAIRE, Charles. Embriaga-te. In: Poetas franceses do século XIX. Tradução e organização de José Lino Grünewald. Rio de Janeiro: Nova Fronteira, 1991, pp. 66-67.

BLIKSTEIN, Izidoro. Kaspar Hauser ou a fabricação da realidade. 9a.. ed. São Paulo: Cultrix, 2003.

BLOCH, Marc. A história, os homens e o tempo. In: Apologia da História ou o ofício do historiador. Tradução de André Telles. Rio de Janeiro: Zahar, 2001.

BURKE, Peter. A história dos acontecimentos e o renascimento da narrativa. In: A escrita da história: novas perspectivas. Tradução de Magda Lopes. São Paulo: UNESP, 1992, p. 327-348.

CANDIDO, Antonio. Formação da literatura brasileira (momentos decisivos). 6aed. Belo Horizonte: Itatiaia, 1981.

. O direito à Literatura. In: Vários escritos. São Paulo: Duas Cidades, 1995.

. Crítica e Sociologia. In: Literatura e Sociedade. Rio de Janeiro: Ouro sobre Azul, 2006, pp. 13-27.

CARRETER, Fernando Lázaro. La literatura como fenómeno comunicativo. In: Estudios de linguística. Barcelona: Crítica, 1980, pp. 173-192.

COMPAGNON, Antoine. O demônio da teoria: literatura e senso comum. Tradução de Cleonice Paes Barreto Mourão, Consuelo Fortes Santiago. 2a -ed. Belo Horizonte: Editora UFMG, 2010.

EAGLETON, Terry. Teoria da Literatura: uma introdução. Tradução de Waltensir Dutra. São Paulo: Martins Fontes, 1994.

ESPRONCEDA, José de. La pata de palo. In: Antología del cuento español. Madrid: Alianza Editorial, 1999, p. 76-81.

HOMERO. Odisseia. Introdução e notas de Médéric Dufour; Jean Raison. Tradução de Antônio Pinto de Carvalho. São Paulo: Abril Cultural, 1979.

ISER, Wolfgang. $O$ ato de leitura: uma teoria do efeito estético. Tradução: Johannes Kretschmer. São Paulo: Editora 34, 1996, v. 1.

. O ato da leitura: uma teoria do efeito estético. Tradução: Johannes Kretschmer. São Paulo: Editora 34, 1999.

JOLLES, André. Formas Simples. Trad. Álvaro Cabral. São Paulo: Cultrix, 1976. 
LACAN, Jacques. Le stade du miroir comme formateur da la fonction du Je. In: Écrits. Paris: Seuil, 1966.

LE GOFF, Jacques. História e memória. Tradução de Bernardo Leitão. São Paulo: UNICAMP, 1990.

LIMA, Luiz Costa. A crítica e o controle. In: O fingidor e o censor: no ancien regime, no iluminismo e hoje. Rio de Janeiro: Forense-Universitária, 1988, pp. 307-352.

. História. Literatura. Fiç̧ão. São Paulo: Companhia das Letras, 2006.

LUKÁCS, Georg. A teoria do romance: um ensaio histórico-filosófico sobre as formas da grande épica. Tradução, posfácio e notas de José Marcos Mariani de Macedo. 2ạed. São Paulo: Duas Cidades; Editora 34, 2009.

MEIRELES, Cecília. Retrato. In: Antologia Poética. São Paulo: Global, 2013. Obra poética ou obras completas. Rio de Janeiro: Nova Aguilar, 1987.

OVIDIO. Metamorfosis. Edição de Consuelo Álvarez; Rosa María Iglesias. Madrid: Cátedra, 2007.

PAZ, Octavio. Signos em rotação. Tradução de Sebastião Uchoa Leite. 2. ed. São Paulo: Perspectiva, 1976.

POUND. Ezra. $A B C$ da literatura. Tradução de Augusto de Campos;José Paulo Paes. 11a ed. São Paulo: Cultrix, 2006.

REIS, Carlos. O conhecimento da literatura: introdução aos estudos literários. Coimbra: Almedina, 1995.

SEGRE, Cesare. La ficción literaria. In: Principios de análisis del texto literário. Barcelona: Crítica, 1985.

SÓFOCLES. Édipo Rei. São Paulo: Abril, 1976.

SOUZA, Eudoro de. História e Mito. Brasília: Cadernos da UNB, 1981.

WILDE, Oscar. The picture of Dorian Gray. In: The Collected Works of Oscar Wilde. Hertfordshire: Wordsworth Editions, 1997.

WHITE, Hayden. O texto histórico como artefato literário. In: Colóquio de Literatura Comparada da Yale University. Connecticut: 1974. 


\title{
Recebido em 27 de maio de 2019.
}

Aceito em 04 de maio de 2020.

\begin{abstract}
${ }^{1}$ V. Poética, 1451a37-1451b7. [Informo que a obra consultada traz a tradução de Paulo Pinheiro, conforme consta nas referências deste trabalho].

${ }^{2}$ É válido reconhecer que essas discussões ainda são vigentes na contemporaneidade. Apesar de todos os estudos amplamente reconhecidos, as produções humanas, como a história e a literatura, não são imunes aos questionamentos ou à atribuição de novas perspectivas. E, especificar sobre a intercomunhão entre essas duas áreas, seja no passado ou no presente, excederia o propósito deste ensaio.
\end{abstract}

3 “[...]ficções verbais cujos os conteúdos são tanto inventados quanto descobertos e cujas formas têm mais em comum com os seus equivalentes na literatura do que com os seus correspondentes nas ciências." (WHITE, 1974, p.98 grifos do autor)

${ }^{4}$ Um pensamento, que também confere um caráter poroso à narrativa literária, seria o de Peter Burke (1992): "[...] "é provável que os historiadores possam aprender algo a partir das técnicas narrativas" (p.340) ". O autor também sinaliza que os historiadores não possuem a liberdade de criar personagens ou os pensamentos destes, o que é algo bastante recorrente na narrativa literária: porosa e permissiva.

${ }^{5}$ Marc Bloch (2001) defende que o homem é o objeto da história. Jacques Le Goff (1990) já aponta o tempo como o motor principal da ciência histórica.

${ }^{6}$ Apesar de na tradução da Poética utilizada para análise constar o vocábulo "evento" tanto para a poesia quanto para a história, a retomada do pensamento aristotélico se pauta no discernimento entre veracidade e sugestão. E, dessa maneira, "fato" é mais adequado à história e "evento" é mais pertinente à literatura.

${ }^{7}$ É válido lembrar que Antonio Candido (1981) tentou demarcar o surgimento de um sistema literário genuinamente brasileiro, a partir da distinção entre manifestações literárias e literatura propriamente dita.

${ }^{8}$ Com respeito à problemática de uma literatura nacional brasileira, sugiro a leitura da conferência de Clodimir Vianna Moog, intitulada Uma interpretação da literatura brasileira (1942). O autor divide o território brasileiro em sete ilhas de influência literária, indicando, assim, a peculiaridade cultural brasileira.

9 "O que você chama de literatura? [...] uma vez reconhecido que os textos literários possuem traços distintivos, você os trata como documentos históricos, procurando neles suas causas factuais. O paradoxo salta aos olhos: você explica pelo contexto um objeto que lhe interessa precisamente porque escapa a esse contexto e sobrevive a ele." (COMPAGNON, 2014, p.22)

${ }^{10}$ Adoto esse termo cunhado por Paulo Pinheiro na sua tradução da Poética de Aristóteles. Nas palavras do autor: "[...] Mimese foi a solução aproximativa utilizada para fazer referência à mimética produtiva ou inventiva, que se distingue da ideia que temos de representação ou de imitação, assim como da imitatio latina, pois não se trata da reapresentação imitativa de um modelo, mas de um modus operandi determinado para reunir, dispor ou compor as ações e acontecimentos trágicos "ocorridos". (PINHEIRO, 2015, p. 09) (grifos do autor). Dessa forma, percebemos que se trata de uma apreensão do real pela diferença.

${ }^{11}$ Me refiro à Teoria do romance: um ensaio histórico-filosófico sobre as formas da grande épica. A edição utilizada para a análise é a de 2009 ( $2^{\mathrm{a}}$ reimpressão - 2015), conforme consta nas referências desse trabalho.

12 "O herói da epopeia nunca é, a rigor, um indivíduo. Desde sempre considerou-se traço essencial da epopeia que seu objeto não é um destino pessoal, mas o de uma comunidade.” (LUKÁCS, 2015, p. 67) 
13 "Ao sair em busca de aventuras e vencê-las, a alma desconhece o real tormento da procura e o real perigo da descoberta, e jamais põe a si mesma em jogo; ela ainda não sabe que pode perder-se e nunca imagina que terá de buscar-se. Essa é a era da epopeia.” (LUKÁCS, 2015, p. 26)

14 "Mas a solidão é algo paradoxalmente dramático: ela é a verdadeira essência do trágico, pois a alma que se fez a si mesma destino pode ter irmãos nas estrelas, mas jamais parceiros." (LUKÁCS, 2015, p. 43)

15 "O romance é a epopeia do mundo abandonado por deus; a psicologia do herói romanesco é a demoníaca; a objetividade do romance, a percepção virilmente madura de que o sentido jamais é capaz de penetrar inteiramente a realidade.” (LUKÁCS, p. 89, 2015)

16 "O círculo em que vivem metafisicamente os gregos é menor do que o nosso: eis por que jamais seríamos capazes de nos imaginar nele com vida; ou melhor, o círculo cuja completude constitui a essência transcendental de suas vidas rompeu-se para nós; não podemos mais respirar num mundo fechado. Inventamos a produtividade do espírito. " (LUKÁCS, 2015, p.30)

17 “A epopeia dá forma a uma totalidade de vida fechada a partir de si mesma, o romance busca descobrir e construir, pela forma, a totalidade oculta da vida. “(LUKÁCS, 2015, p.60)

${ }^{18}$ Georg Lukács está se referindo a Dom Quixote de Miguel de Cervantes.

${ }^{19}$ Entende-se por revelação poética aquela que é presidida pelas leis da imagem e do ritmo, conforme Octávio Paz (1976).

20 "Como o leitor passa por diversos pontos de vista oferecidos pelo texto e relaciona suas diferentes visões e esquemas, ele põe a obra em movimento, e se põe ele próprio igualmente em movimento" (ISER, 1985, p.21)

21 "Se não é possível ver a literatura como uma categoria "objetiva", descritiva, também não é possível dizer que a literatura é apenas aquilo que, caprichosamente, queremos chamar de literatura". (EAGLETON, 1994, p.17 grifos do autor).

22 "A falta de assistência do autor ao ato comunicativo implica que não existe um contexto necessariamente compartilhado entre o destinatário e o emissor. Mas, se por definição, o contexto para que a comunicação se produza. Onde haveremos de buscá-lo? Apenas em um lugar: na obra mesma. Esta, a obra, comporta seu próprio contexto. A mensagem literária remete essencialmente a si mesma." (CARRETER, 1980, p.160) [Todos os textos retirados de obras literárias em língua estrangeira foram trazidos por mim ao Português.]

${ }^{23}$ Énivrez-vous

${ }^{24}$ Trata-se do personagem principal do romance The Picture of Dorian Gray (1890).

25 "A alma do herói repousa, fechada e perfeita em si mesma, como uma obra de arte ou uma divindade; mas essa essência só pode exprimir-se no mundo exterior em aventuras inadequadas.” (LUKÁCS, 2015, p.103)

26 “A vida só é possível reinventada” (MEIRELES, 1987, p.195) 